Pecvnia, 1 (2005), pp. 31-66

\title{
Cuestiones actuales del régimen jurídico-administrativo de las cajas de ahorros españolas
}

Las reformas legislativas que han afectado en los últimos tiempos a la organización y el funcionamiento del sistema financiero español han tenido una especial repercusión en el ámbito de las cajas de ahorros. La tramitación parlamentaria de la Ley 44/2002, de 22 de noviembre, de Medidas de Reforma del Sistema Financiero, reavivó el debate sobre su régimen jurídico y la necesidad de acotar la intervención pública en su seno. Ahonda en ello la Ley $26 / 2003$, de 17 de julio, de Transparencia, que extiende al ámbito de las cajas la preocupación por el corporate governance. Ambas normas responden a la necesidad de dar respuesta a algunos de los problemas más inmediatos a que se enfrentan estas entidades, si bien adolecen de un defecto fundamental por cuanto no abordan de forma exhaustiva la regulación de la institución. Se perpetúa así la trayectoria tradicional de «parcheo» del régimen jurídico aplicable a las mismas, evitando entrar en la cuestión esencial de la definición de su naturaleza jurídica y abocando a las cajas, en consecuencia, al difícil reto de acompasar su vocación social tradicional a las nuevas exigencias legales en pro de una mayor eficiencia, racionalidad y neutralidad de su actividad económica.

\author{
Anabelén Casares Marcos
}


Palabras clave: caja de ahorros; fundaciónempresa; intervención pública; cuota participativa; gobierno corporativo.
Key words: savings bank; non-profit foundation company; public influence; non-voting equity unit; corporate governance.

\section{INTRODUCCIÓN}

El Real Decreto de 25 de octubre de 1838, por el que se crea la Caja de Ahorros de Madrid, supone la implantación oficial de estas entidades en España; a medio camino entre lo benéfico y lo financiero, ofrecen desde sus comienzos un perfil y una naturaleza jurídica de difícil catalogación. Nacen con un retraso considerable respecto a las cajas europeas, lo que no impide, sin embargo, su rápida propagación al socaire de una particular filosofía que las avala como solución eficaz a los males propios de la sociedad de la época ${ }^{1}$.

La principal característica que define la evolución de su actividad económica desde su nacimiento en el siglo XIX es su avance y expansión decidida en todos los mercados del sistema financiero español. En la actualidad controlan el 48,80 por 100 de los recursos ajenos, situándose la cuota de créditos sobre clientes en el 47,96 por $100^{2}$. Representan una parte importante, por no decir trascendental, de nuestro sistema financiero.

$Y$ sin embargo, se trata de una institución crediticia a la que se aplica un régimen jurídico del todo peculiar en atención a sus

1 Y así, para Ángel Pascual Martínez Soto (2000: 623), no deja de llamar la atención la importancia que llegaron a alcanzar en las últimas décadas del siglo XIX español "a pesar de su desarrollo limitado en comparación con el que obtuvieron en países de nuestro entorno".

2 Estos datos corresponden a noviembre de 2004 y se extraen del informe de la Confederación Española de las Cajas de Ahorros (CECA) hecho público a través de nota de prensa de 16 de febrero de 2005. Deja constancia de cómo las cajas de ahorros españolas han ganado cuota en todos los mercados del sistema financiero español, situándose los recursos ajenos en 514.452 millones de euros en diciembre de 2004, con un crecimiento del 14,6 por 100 sobre el año anterior y un avance de 1,11 puntos en la cuota de las cajas respecto al resto de los intermediarios financieros. En cuanto al crédito, las cajas alcanzaron la cifra de $\mathbf{4 5 0 . 9 0 6}$ millones de euros en diciembre de 2004, con un incremento de la cartera del 20,7 por 100 , ascendiendo su inversión total a 550.738 millones de euros, un 15,5 por 100 más que el año anterior, y la cuota en créditos sobre clientes al 47,96 por 100 tras haber avanzado 1,01 puntos en los doce meses previos. Con datos definitivos del cierre del ejercicio, la cuota de mercado en fondos de inversión avanzó también 0,54 puntos durante 2004 hasta alcanzar el 27,72 por 100 y situarse el patrimonio gestionado por las cajas en este ámbito en 60.480 millones de euros. Sobre los resultados económicos de las cajas de ahorros españolas, vid., asimismo, la Memoria de la supervisión bancaria en España, correspondiente al año 2003 del Banco de España y el Informe Actualidad del sector financiero, correspondiente al tercer trimestre de 2004, de la consultoría Tatum (accesible en www.tatum.es). 
fines, objetivos y vocación tradicionalmente social. Frente a las diversas cuestiones que suscita en el foro político español, ya sea estatal o autonómico, y a las dudas que plantean ciertos aspectos concretos de su actuación y regulación, se impone la necesidad imperiosa de responder a un interrogante fundamental, susceptible de condicionar su régimen jurídico: ¿Qué es una caja de ahorros?

La ambigüedad de muchos pronunciamientos normativos y jurisprudenciales habidos en la materia, la ausencia en su seno de propietarios en sentido estricto, y la pervivencia, en fin, de alguno de sus rasgos tradicionales, han contribuido a enmarañar la cuestión, erosionando la autonomía originaria de la caja de ahorros y arrinconándola en tierra de nadie. No cabe duda que la indeterminación de su propia concepción y de su naturaleza jurídica ha condenado a las cajas a un permanente destierro del plano institucional ordinario, obligándolas a habitar un limbo permanente en el que tan pronto se las califica de "entes de origen fundacional", como de "fundaciones" en sentido estricto, "entidades de crédito" o, simplemente, "entes de naturaleza social".

Así las cosas, los poderes públicos han acabado por tomar las riendas de la organización y gestión de estas entidades de crédito, en aras precisamente de la protección y promoción de su función social. Una "publificación" que ha desembocado, sin duda, en una auténtica "politización" y en una pugna de intereses de uno y otro signo en la integración de los órganos de gobierno de la caja de ahorros y en la adopción de muchas de sus decisiones económicas. Ha llamado la atención sobre ello la propia Unión Europea, que amenaza con considerar a las cajas españolas, a efectos del Derecho comunitario de la competencia, como entidades públicas al amparo de la influencia dominante que corresponde en su gobierno a los poderes públicos.

De ahí la necesidad de adoptar, en mi opinión, un enfoque general capaz de descubrir, ordenar y actualizar la verdadera columna vertebral del régimen jurídico aplicable a estas entidades crediticias, que no es otra, en definitiva, que su dimensión constitucional y administrativa. Sólo así estarán las cajas españolas en situación de responder adecuadamente a los retos planteados por las reformas legislativas de los últimos tiempos y por la propia evolución del sistema financiero español, garantizándose su supervivencia y la de la vocación social que las ha acompañado desde sus orígenes. 
ESPAÑOLAS

\section{LA NATURALEZA JURÍDICA DE LAS CAJAS DE AHORROS}

1. La evolución histórica de la caja de ahorros: de institución privada de beneficencia a entidad de crédito

Las cajas de ahorros surgen en España como remedio a los problemas económicos sufridos por los montes de piedad, sus antecedentes institucionales más inmediatos. Su nacimiento es, en definitiva, una consecuencia lógica al devenir histórico, jurídico y económico de los montes, y a la necesidad que éstos experimentaban, a comienzos del siglo $\mathrm{XIX}$, de encontrar nuevas vías de financiación con las que ampliar aún más sus operaciones de préstamo benéfico pignoraticio ${ }^{3}$.

El fin filantrópico, incluso benéfico y caritativo, que anima a todas estas entidades de crédito desde sus orígenes, y que se transmite y hereda de unas a otras, contribuirá decisivamente a la configuración jurídica posterior de la caja de ahorros y a su distinción e individualización tanto del resto de las entidades benéficas como de las instituciones bancarias existentes.

Así se refleja en la Real Orden de 3 de septiembre de 1835, primera disposición oficial española que versa sobre las cajas de ahorros, cuyo texto resume las condiciones políticas y económicas vigentes y alaba la creación de estas instituciones "donde el menestral, el jornalero y todo hombre laborioso puede depositar sumas muy tenues bajo la confianza de obtener un rédito proporcionado, de capitalizar los intereses en cortos períodos, y de realizar sus fondos en todo tiempo".

Insiste también en ello la exposición de motivos del Real Decreto de 25 de octubre de 1838, de fundación de la Caja de Ahorros de Madrid, mostrándose la Reina Doña María Cristina "deseosa de mejorar la suerte y las costumbres de estas clases tan dignas de mi maternal

3 Ahora bien, los precedentes de las cajas de ahorros españolas se remontan aún más en el tiempo, ya que la estructura y actividad crediticia de los montes de piedad había estado bajo la influencia, a su vez, de dos corrientes diversas. En efecto, los montes de piedad surgen en España a consecuencia de la confluencia de una corriente autóctona, representada por una serie de antecedentes institucionales netamente españoles que se remontan en el tiempo a épocas medievales, y de una corriente puramente italiana, que bebe directamente de las disputas planteadas en Italia desde el siglo XV en torno a la propia existencia y justificación de los montes de piedad. Sobre los antecedentes históricos de las cajas de ahorros españolas, su nacimiento y evolución jurídiconormativa posterior, vid., con mayor profundidad, Anabelén Casares Marcos (2000), y la bibliografía allí citada; así como, Papeles de Economía Española (2003), monográfico dedicado a los orígenes de las cajas de ahorros. 
solicitud, estimulando su laboriosidad, economía y previsión". El éxito de esta primera caja contribuyó a que la Real Orden de 17 de abril de 1839 la erigiera en el modelo a seguir por el resto de las cajas de ahorros que progresivamente se fueran creando en España ${ }^{4}$.

El éxito de la institución y la propia evolución política y socioeconómica del país modificarían con el paso del tiempo esta vinculación inicial al ámbito de la beneficencia motivando los primeros pronunciamientos normativos en la materia, de vocación claramente uniformadora e intervencionista. Frente a su autonomía estatutaria inicial, las cajas de ahorros acabarían, en definitiva, por someterse a un régimen jurídico peculiar, integrado tanto por la legislación específica dictada para su organización como por la legislación de beneficencia. Con el paso del tiempo acusarían, inevitablemente, las dificultades y complejidades existentes en ambos sectores del ordenamiento.

En efecto, tanto el Real Decreto de 29 de junio de 1853 como la Ley de 29 de junio de 1880 son dictados con el propósito de regular un sector emergente pero de gran éxito, el de las cajas de ahorros, en el que los estatutos y reglamentos de cada entidad habían sido hasta entonces las únicas y verdaderas normas ordenadoras de su organización y actividad, eminentemente benéficas.

Los primeros años del siglo XX traen consigo, en cualquier caso, el desplazamiento del carácter benéfico de la institución y la introducción en su actividad, por el contrario, de la idea social ${ }^{5}$. Este proceso culminaría finalmente en los Reales Decretos-leyes de 9 de abril de 1926 y de 21 de noviembre de 1929, que suponen el expreso reconocimiento del cambio cualitativo producido en los fines y funciones de las cajas de ahorros españolas.

4 A ello contribuyó también la importante labor de difusión que realizaría en este sentido Don Braulio Antón Ramírez, Director de la Caja de Ahorros de Madrid desde 1871 hasta 1892. Para un estudio en profundidad de la aportación de Antón Ramírez a las cajas españolas y de su obra, vid. Carlos Hornillos, José López Yepes y Faustino Vellosillo (1972 a), (1972 b) y (1972 c); así como, José López Yepes y Manuel Titos Martínez (2000).

5 La separación entre montes de piedad y cajas de ahorros, propiciada por la legislación específica dictada para estas últimas y por el crecimiento espectacular de sus depósitos, hace cada vez más difícil su configuración como entidades estrictamente benéficas. De ahí el interés que presenta el estudio de la legislación decimonónica aplicable a las cajas de ahorros y reveladora de este proceso de evolución paulatina desde su consideración como establecimientos estrictamente benéficos de naturaleza fundacional hasta su identificación como entidades de crédito social a las que se reconoce el estatuto protector de las instituciones de beneficencia. 
Ambos textos contienen, además, la semilla de la futura consideración de las cajas de ahorros como entidades financieras, una idea que se irá consolidando lentamente y que cristalizará, finalmente, en el Estatuto para las Cajas Generales de Ahorro Popular, aprobado por Decreto de 14 de marzo de 1933. El Estatuto sienta, asimismo, las bases para una vinculación cada vez más estrecha de la actividad crediticia de estas entidades de ahorro a la financiación de actuaciones esencialmente públicas ${ }^{6}$.

No se ha aprobado desde entonces una norma que pretenda la regulación total o unitaria del régimen jurídico aplicable a las cajas de ahorros, sino tan sólo pronunciamientos parciales o sectoriales relativos a aspectos más o menos concretos de su funcionamiento y organización. En este sentido, destaca por su trascendencia económica la plena equiparación funcional y operativa de las cajas con la banca privada a raíz de la Reforma Fuentes Quintana, materializada en los Reales Decretos 2290/1977, de 27 de agosto, sobre regulación de los órganos rectores de las cajas de ahorros, y 2291/1977, de idéntica fecha, sobre la regionalización de sus inversiones ${ }^{7}$.

La regulación que se establece entonces de sus órganos de gobierno será rota por la Ley $31 / 1985$, de 2 de agosto, de Regulación de Normas Básicas sobre los Órganos Rectores de las Cajas de Ahorros (LORCA). Con este texto se pretende, conforme a los objetivos confesados expresamente en su exposición de motivos, adaptar las cajas de ahorros a las circunstancias políticas y económicas existentes tras la promulgación de la Constitución de 1978 y consagrar el principio de representatividad y democratización en sus órganos de gobierno, todo ello sin romper con la función social que de forma continuada han venido ejerciendo desde su fundación ${ }^{8}$.

6 Es pieza clave, en este sentido, el Instituto de Crédito de las Cajas Generales de Ahorro que, creado por otro Decreto de igual fecha que el del Estatuto de 1933, se alza como intermediario financiero en las relaciones entre las cajas de ahorros y el sector público. Vid. Anabelén Casares Marcos (2000: 162 y ss).

Esta reforma trae causa de la Base $5 .^{a}$ de la Ley de 14 de abril de 1962 , de Bases de Ordenación del Crédito y la Banca, que amplía el ámbito operacional de las cajas de ahorros españolas abriendo una tendencia que habría de culminar en la reforma de 1977.

Sobre la transición de las cajas de ahorros desde el ámbito estrictamente benéfico y asistencial, pasando por la vertiente social a comienzos del siglo XX y por su plena equiparación operacional con la banca en 1977, hasta su pertenencia actual al que es conocido como "Tercer Sector", vid. Anabelén Casares Marcos (2002: 487 y ss). 
En todo caso, el reconocimiento constitucional de un nuevo centro territorial de poder, la Comunidad Autónoma, marcará también la evolución posterior de las cajas de ahorros, especialmente durante los veinte años que separan la LORCA del momento actual ${ }^{9}$. A la consolidación definitiva de su calificación como entidades de crédito durante este último período de su evolución, consecuencia de la adaptación del ordenamiento jurídico español a la normativa comunitaria en el ámbito financiero, se sumará, además, un proceso, abierto aún, de "regionalización" de la vocación social y la inversión económica de las cajas, así como de abierta pugna política por el control de sus órganos gestores y de gobierno, al socaire de la ausencia en ellas de propietarios y del interés general que debe presidir su actuación ${ }^{10}$.

2. La teoría de la fundación-empresa y el régimen jurídico actual de la caja de ahorros

A) El problema de la naturaleza jurídica de la caja de ahorros

El éxito económico de las cajas de ahorros españolas tras más de 150 años de historia es incontestable. Su situación financiera ha sido siempre muy distinta a la de sus homónimas europeas. Si estas últimas se vieron compelidas, durante los años ochenta y noventa, a transformarse en sociedades por sus dificultades para cumplir con la normativa europea en materia de recursos propios, las cajas españolas, por el contrario, se han caracterizado por una situación saneada y por la facilidad con la que

9 Las tensiones competenciales desatadas entre el Estado y las Comunidades Autónomas en este ámbito llevaron a Sebastián Martín-Retortillo Baquer (1991: 252), a hablar de un "auténtico campo de Agramante".

10 Hitos de este proceso son, entre otros, el Real Decreto Legislativo 1298/1986, de 28 de junio, por el que se adapta la legislación española en materia de establecimientos de crédito al ordenamiento jurídico de la Comunidad Económica Europea; la Ley 26/1988, de 29 de julio, de Disciplina e Intervención de las Entidades de Crédito; la Ley 3/1994, por la que se adapta la legislación española en materia de entidades de crédito a la segunda Directiva de coordinación bancaria y se introducen otras modificaciones relativas al sistema financiero; la Ley 44/2002, de 22 de noviembre, de Medidas de Reforma del Sistema Financiero; y, finalmente, la Ley 26/2003, de 17 de julio, por la que se modifican la Ley 24/1988, de 28 de julio, del Mercado de Valores, y el Texto Refundido de la Ley de Sociedades Anónimas, aprobado por el Real Decreto Legislativo 1564/1989, de 22 de diciembre, con el fin de reforzar la transparencia de las sociedades anónimas cotizadas. A ello habría que sumar también la normativa sobre cajas de ahorros aprobada por las Comunidades Autónomas españolas en ejercicio de sus competencias en la materia, así como los sucesivos pronunciamientos del Tribunal Constitucional respecto a la constitucionalidad de las disposiciones legislativas en materia de cajas y a la articulación del reparto competencial en este ámbito. 
se han adaptado a las exigencias del mercado único sin necesidad de alterar su naturaleza jurídica tradicional.

La destacada posición que ocupan en el sistema financiero español y la ausencia en ellas, hasta el momento, de dificultades financieras similares a las de algunas cajas de ahorros europeas, no ocultan, sin embargo, los inconvenientes derivados de su configuración institucional a efectos de su competencia en el mercado. Debido a su naturaleza fundacional, su capitalización resulta más compleja que la de otras instituciones financieras, lo que ha suscitado periódicamente la reflexión y el debate, fundamentalmente político, sobre la necesidad de reformar su naturaleza jurídica.

La oportunidad y conveniencia de una reforma semejante y de su inserción en el ámbito societario ofrecen, en mi opinión, dudas importantes en el momento actual, sobre todo si se toma en consideración la flexibilidad y facilidad de adaptación que ha caracterizado a las cajas de ahorros españolas a lo largo de su evolución y que ha llevado a convertirlas en elementos esenciales del mercado financiero español.

Son muchos los argumentos, tanto a favor como en contra, de la conversión de nuestras cajas de ahorros en sociedades, si bien la necesidad de velar por su función social incorpora al debate, además de los elementos propios del discurso meramente económico, la necesidad imperiosa de garantizar y proteger, con posterioridad a su posible transformación, la inmunidad de la caja frente a una adquisición hostil, a fin de garantizar el interés general que debe regir su actividad y que subyace a su propia existencia.

No cabe ignorar las enseñanzas derivadas de las experiencias comparadas en Europa. En todas ellas se ha constatado que, por muchas precauciones que se quieran adoptar para garantizar los rasgos originarios más característicos y propios de las cajas, éstos acaban por desaparecer, desembocando, inevitablemente, en la equiparación absoluta e identificación total entre cajas de ahorros y bancos comerciales ${ }^{11}$.

11 Así lo sostiene también Jack Revell (1989: 141 y ss.) que entiende que una vez abierto el proceso resulta difícil detenerlo en un estadio intermedio. Sobre la experiencia comparada de las cajas de ahorros europeas y el debate doctrinal abierto respecto a la "privatización" de las cajas españolas a través de su conversión en sociedades, vid. Anabelén Casares Marcos (2003: 507 y ss.) y la doctrina allí citada. 
La experiencia comparada avala, por tanto, la evolución de las cajas españolas y las convierte, paradójicamente, en el modelo a seguir. El éxito de su gestión, no sólo en el ámbito social, sino también desde una perspectiva estrictamente financiera, supone, en definitiva, un respaldo evidente a la configuración y actividad de estas entidades y contribuye a alimentar, aún más si cabe, los recelos sobre su posible privatización ${ }^{12}$.

Es cierto, no obstante, que se perfilan como necesarias, y absolutamente perentorias, ciertas modificaciones de su régimen jurídico y un desarrollo legislativo pormenorizado de las implicaciones derivadas de su naturaleza jurídica fundacional, tanto desde la perspectiva de su actividad empresarial como de su fin de interés general. Sólo así se garantizará la pervivencia de su función social y se evitará que la institución muera víctima de su propio éxito.

Es patente la insuficiencia de la normativa existente actualmente en la materia para responder a todas las dudas e interrogantes que plantea esta entidad crediticia en el ordenamiento jurídico español. Un dato confirmado, además, por la ausencia de una ley general sobre la institución en el ámbito estatal. No se ha dictado una norma general relativa a cajas de ahorros desde 1933, centrándose la regulación posterior tan sólo en aspectos concretos relativos, fundamentalmente, a su organización interna ${ }^{13}$.

No es de extrañar que, amparadas en el silencio estatal, las Comunidades Autónomas, que han asumido competencias en la materia sobre la base del artículo 149.1.11 de la Constitución española de 1978, se hayan lanzado a dictar normas más amplias, comprensivas de extremos ignorados en la legislación estatal, definiendo su concepto, declarando en ocasiones su naturaleza jurídica fundacional y concretando las exigencias

12 Para Rafael López del Paso (2003: 150) las cajas españolas se sitúan como un "modelo llamado a persistir y a perpetuarse a lo largo del tiempo" dado el grado de satisfacción de la sociedad hacia ellas y de su éxito económico. En sentido similar, María José Vañó Vañó (2000 a: 11388) para quien no existen razones objetivas que justifiquen la transformación de la naturaleza tradicional de las cajas de ahorros españolas.

13 Para Juan Sánchez-Calero Guilarte (2003: 441 y ss.) no cabe duda que la reciente Ley Financiera sigue esa misma tendencia de "preocupación por lo inmediato y desdén hacia una regulación que aporte estabilidad y aleje a las cajas del debate y pugna políticos, teñido siempre de oportunidad y parcialidad". 
y requisitos a que deben sujetarse las manifestaciones específicas de su función social ${ }^{14}$.

La ausencia de una declaración expresa en el ámbito estatal sobre la naturaleza de las cajas de ahorros españolas se debe, en buena medida, a la pugna de intereses, fundamentalmente políticos, que se ha desatado en su seno como consecuencia de su estructura de gobierno y de la ausencia en ellas de títulos de propiedad. El debate ha desembocado en la defensa por parte de los poderes públicos de una posición absolutamente peculiar, ya que si de un lado se niega la naturaleza fundacional de las cajas de ahorros, de otro se acude a su identificación originaria como instituciones de beneficencia y a los rasgos que confluyen en ellas y que las conectan con el interés general para justificar una presencia pública cualificada en su constitución, organización y actuación misma.

El Tribunal Constitucional ha otorgado carta de naturaleza a esta postura al negar el carácter fundacional de las cajas de ahorros españolas en su Sentencia 49/1988, de 22 de marzo, dictada como consecuencia de los recursos de inconstitucionalidad promovidos contra la LORCA. No acepta la tesis que las identifica con fundaciones "en el sentido del artículo 34 de la Constitución", si bien encuadra su naturaleza jurídica en el artículo 35 del Código civil español "en la categoría de las fundaciones, a las que se asemejarían por el hecho de que no consiste en

14 Vid., en este sentido, los artículos 2 de la Ley Foral 7/1987, de 21 de abril, de órganos rectores de las Cajas de Ahorros de Navarra; 2 de la Ley 1/1991, de 4 de enero, de Cajas de Ahorro de Aragón; 1.2 del Texto Refundido de Cajas de Ahorros de Cataluña, aprobado por Decreto Legislativo 1/1994, de 6 de abril; 1.2 de la Ley 8/1994, de 23 de diciembre, de Cajas de Ahorros de Extremadura; 1.2, 2 y 6 de la Ley 4/1996, de 31 de mayo, de Cajas de Ahorro de Galicia, plagada de referencias a la doble naturaleza fundacional y financiera de estas entidades, tanto en su Preámbulo como en su articulado; 1.2 de la Ley 4/1997, de 10 de julio, de Cajas de Ahorro de Castilla-La Mancha; 1.2 del Texto Refundido de las Normas reguladoras de las Cajas de Ahorros de la Comunidad Valenciana, aprobado por Decreto Legislativo 1/1997, de 23 de julio; 1.2 de la Ley 3/1998, de 1 de julio, de Cajas de Ahorro de la Región de Murcia; 2.1 de la Ley 15/1999, de 16 de diciembre, de Cajas de Ahorros de Andalucía; 1.2 de la Ley $2 / 2000$, de 23 de junio, de Cajas de Ahorro del Principado de Asturias; 2.1 de la Ley 5/2001, de 4 de julio, de Cajas de Ahorros de Castilla y León; 1.2 de la Ley 4/2002, de 24 de julio, de Cajas de Ahorro de Cantabria; y, por último, 2.1 de la Ley 6/2004, de 18 de octubre, de Cajas de Ahorro de La Rioja. Las definiciones que acogen estos preceptos proclaman de forma expresa el origen o la naturaleza fundacional de las cajas de ahorros, por lo que contrastan con el silencio que mantienen en esta cuestión, por el contrario, los conceptos meramente descriptivos y totalmente asépticos que ofrecen, por ejemplo, los artículos 1.2 y 3 de la Ley 13/1990, de 26 de julio, sobre regulación de las Cajas de Ahorros de Canarias; 1.2 de la Ley 3/1991, de 8 de noviembre, de regulación de las Cajas de Ahorros Vascas; o, 1.1 del Decreto 42/2003, de 2 de mayo, por el que se modifica el Decreto 92/1989, de 19 de octubre, de regulación de órganos rectores de las Cajas de Ahorros con domicilio social en las Illes Balears. Aún más escurridiza resulta la Ley 4/2003, de 11 de marzo, de Cajas de Ahorros de la Comunidad de Madrid, cuyo artículo 2 se refiere a su "naturaleza particular como cajas y entidades de crédito". 
una unión de personas, que en cierto modo aparecen como los propietarios de sus bienes, sino de una organización de los bienes mismos como ocurre en las fundaciones de tipo tradicional". Advierte el propio Tribunal que:

\begin{abstract}
esta aplicación de una categoría jurídica a un supuesto distinto para el que fue pensada es posible, siempre que no se extraigan de ella consecuencias abusivas y se la considere sólo como un medio de resolver un problema dogmático, cual sería en este caso la naturaleza jurídica de las cajas.
\end{abstract}

De esta doctrina no cabe sino concluir la existencia de dos tipos de fundaciones, aquellas que responden al derecho fundamental recogido en el artículo 34 de la Constitución, y aquellas otras que sin alcanzar su protección, encajan sin embargo en el artículo 35 del Código civil a efectos "meramente dogmáticos".

Pero es que esta Sentencia excluye, además, a las cajas de ahorros del ámbito de la libertad de empresa del artículo 38 de la Constitución, puesto que "dicho precepto se refiere a empresas privadas, es decir, a organizaciones que tienen una finalidad de lucro, y garantiza en último término la existencia de una economía de mercado", mientras que:

las cajas no pueden tener aquella finalidad ni persiguen distribuir beneficios, sino que el excedente de sus rendimientos lo han de dedicar a obra social, con lo que de nuevo vuelve a aparecer el interés público en su gestión y su carácter atípico, pues se trataría, en todo caso, de entidades sin fin de lucro, lo que ciertamente no responde al concepto tradicional de empresa.

Siguiendo el razonamiento del Tribunal Constitucional cabe, por tanto, separar las entidades de crédito españolas en dos grupos diferenciados. El primero, integrado por las cajas de ahorros a las que no alcanza el "concepto tradicional de empresa" ni, en consecuencia, la garantía del artículo 38 de la Constitución. El segundo, formado por el resto de las entidades crediticias que operan en el sistema financiero español a las que sí alcanza esta protección.

La cuestión de la naturaleza jurídica de las cajas, a la vista de las contradicciones e imprecisiones flagrantes en que ha incurrido el Tribunal Constitucional al abordar el tema, no resulta en absoluto 
inoportuna ${ }^{15}$. Tanto éste como el Tribunal Supremo han afirmado en diversas ocasiones la naturaleza privada de las cajas; las dudas continúan, a pesar de ello, en pie. $Y$ es que la jurisprudencia constitucional ha excluido expresamente a las cajas de ahorros del ámbito de los artículos 34 y 38 de la Constitución, acuñando con ello una nueva etiqueta, la de "entes sociales", que se aplica a las cajas cada vez que resulta necesario abordar el problema de su naturaleza jurídica o el del interés general que persiguen ${ }^{16}$.

Resultado de todo ello ha sido la dificultad, incapacidad incluso, del legislador en el pasado para dar con una regulación apropiada a estas entidades, que permitiera el equilibrio y el respeto en su seno de elementos propiamente fundacionales y de otros claramente empresariales, y la pervivencia de un maremágnum de normas, anacrónicas y desfasadas las más de las veces, en las que desarrolla su régimen jurídico la institución, así como la imposibilidad de zanjar una conflictividad, ya tradicional en el sector, que ha llevado ante el Tribunal Constitucional a buena parte de las normas estatales y autonómicas dictadas en la materia ${ }^{17}$.

15 Y así, Juan Sánchez-Calero Guilarte (2003: 449) recuerda que la determinación de la naturaleza jurídica de una concreta institución "ha de servir para la adecuada construcción de su régimen legal".

16 Entre estos pronunciamientos constitucionales, destacan especialmente las Sentencias 1/1982, de 28 de enero; 18/1984, de 7 de febrero; $91 / 1984$, de 9 de octubre; 48 y 49/1988, de 22 de marzo; 178/1992, de 13 de noviembre; 239/1992, de 17 de diciembre; 61 y 62/1993, de 18 de febrero; 155/1993, de 6 de mayo; 96/1996, de 30 de mayo; y, 10/2005, de 20 de enero.

17 A las Sentencias citadas en la nota anterior habría que añadir, además, la admisión a trámite del recurso de inconstitucionalidad número 453/2000, promovido por el presidente del Gobierno de la Nación contra determinados preceptos de la Ley 15/1999, de 16 de diciembre, de Cajas de Ahorros de Andalucía (concretamente las letras b), c) y f) del apartado primero del artículo 44 y los apartados $2 .^{\circ}$ y $3 .^{\circ}$ de la disposición adicional primera), y respecto al cual acuerda el Tribunal Constitucional, en su Auto 178/2000, de 13 de julio, levantar la suspensión del artículo 44.1 b), c) y f) y mantener la de la disposición adicional primera números 2 y 3, y en su Auto de 2 de febrero de 2005, tener por desistido al Presidente del Gobierno de la Nación, declarando extinguido el proceso. La discrepancia entre Gobiernos nacional y autonómico andaluz sobre el régimen aplicable a las cajas de fundación eclesiástica, llevó al Consejo de Gobierno de la Junta de Andalucía a promover el conflicto positivo de competencia número 3933/2003, en relación con una Orden de 13 de marzo de 2003, del Ministerio de Economía, por la que se autoriza la modificación de los Estatutos y el Reglamento del procedimiento para la designación de los órganos de gobierno de la entidad Caja de Ahorros y Monte de Piedad de Córdoba, admitido a trámite por el Tribunal Constitucional por providencia de 15 de julio de 2003. Ténganse en cuenta también el Conflicto en defensa de la autonomía local número 460/2001, promovido por veinte municipios del Principado de Asturias, en relación con diversos preceptos de la Ley asturiana $2 / 2000$, de 23 de junio, de Cajas de Ahorro, y admitido a trámite por providencia del Tribunal Constitucional de 10 de diciembre de 2002, y los recursos de inconstitucionalidad número 5119 y 5120/2003, promovidos, respectivamente, por más de cincuenta Diputados del Grupo Parlamentario Popular y por más de cincuenta Diputados del Grupo Parlamentario Socialista contra determinados preceptos de la Ley 3/2003, de 7 de mayo, del Parlamento Vasco, que modifica otros de la Ley 3/1991, de Cajas de Ahorro de la Comunidad Autónoma del País Vasco, admitidos a trámite por sendas providencias de 16 de julio de 2003. Asimismo, es preciso tomar en consideración la cascada de recursos de inconstitucionalidad interpuestos contra 
No se trata, en todo caso, de una cuestión baladí, ya que la naturaleza jurídica de la caja de ahorros, como la de cualquier otra institución, va a condicionar de forma tajante el régimen jurídico que le resulte de aplicación. Es una realidad que traspasa, en definitiva, el ámbito doctrinal o teórico para plasmarse en la práctica cotidiana de la entidad. De ahí que la postura adoptada por el Tribunal Constitucional sea, a mi entender, absolutamente inapropiada para resolver un problema de semejante calado jurídico y trascendencia económica.

Suscita, cuando menos, perplejidad la negación tanto de su vertiente empresarial, debido a la finalidad de interés general presente en la institución, como de su vertiente fundacional, sobre la base de su condición de entidad de crédito. Ambas facetas están indisolublemente unidas en la caja de ahorros, cuya pervivencia y éxito depende, en buena medida, de que se respete el contenido esencial de cada una de ellas y su equilibrio interno en la institución.

\section{B) La caja de ahorros como fundación-empresa}

El Tribunal Constitucional pierde en 1988 una oportunidad histórica para pronunciarse con nitidez sobre la naturaleza jurídica de estas entidades y sobre los límites a la intervención pública, y fundamentalmente política, en su seno. En sus sucesivas Sentencias el Tribunal desecha los fundamentos que se le presentan argumentando lo que "no" son las cajas, pero sin definir en ningún momento lo que son en realidad.

Habría sido deseable una mayor claridad en la materia y un pronunciamiento expreso en 1988 sobre la naturaleza de las cajas como fundaciones-empresa, amparadas por las garantías que consagran los artículos 34 y 38 de la Constitución. Con su silencio el Tribunal ha eliminado cualquier posible restricción sobre la base de estos artículos, consagrado, por el contrario, un régimen de intervención sin barreras de los poderes

\footnotetext{
las reformas que introduce en el régimen jurídico de las cajas de ahorros la Ley 44/2002, de 22 de noviembre, de Medidas de Reforma del Sistema Financiero, y admitidos a trámite por el Tribunal Constitucional: recurso de inconstitucionalidad 1004/2003, promovido por el Consejo de Gobierno de la Junta de Comunidades de Castilla La Mancha contra los apartados 2, 5, 6, 10, 11 y 17 de su artículo 8 , artículos $14,29,30$ y 31 , Disposiciones Transitorias $10 .^{\mathrm{a}}$ y $12 .^{\mathrm{a}}$, así como el penúltimo párrafo de la Disposición transitoria 11. ${ }^{\text {a }}$; recurso de inconstitucionalidad 893/2003, promovido por el Consejo de Gobierno de la Junta de Andalucía contra los apartados 2, 3, 5, 10, 15 y 17 de su artículo 8 y Disposición final $1 .^{\text {a }}$; recurso de inconstitucionalidad 488/2003, promovido por el Presidente del Parlamento Andaluz contra los apartados 1, 2, 4, 5, 6, 9, 10, 11, 12, 14, 15 y 17 de su artículo 8 Disposiciones transitorias $10 .^{\mathrm{a}}$ y $11 .^{\mathrm{a}}$ y Disposición final $1 .^{\mathrm{a}} ; \mathrm{y}$, por último, recurso de inconstitucionalidad $845 / 2003$, promovido por más de 50 Diputados del Grupo Parlamentario Socialista contra los apartados 15 y 17 de su artículo 8.
} 
públicos en ámbitos que corresponden, en realidad, a la gestión y a la adopción de decisiones estrictamente económicas.

Y sin embargo, la caja es el exponente más cualificado de la teoría de la fundación-empresa en el ordenamiento jurídico español por la claridad con que se concilian en ella dos extremos en principio incompatibles: la realización de una obra social de interés general y el ejercicio en el mercado de la actividad crediticia.

La constitucionalidad y admisibilidad de la fundación-empresa en nuestro ordenamiento jurídico es indiscutible y deriva de la conexión necesaria de los artículos 34 y 38 de la Constitución. Es preciso ser coherentes con el texto constitucional, interpretarlo en su conjunto y abrir el ámbito fundacional a un mayor grado de libertad patrimonial, compatible, en todo caso, con los controles administrativos que sean considerados necesarios para garantizar la finalidad última de la institución, conectada inevitablemente con el interés general.

La fundación-empresa supone, en cualquier caso, la constitución de una persona jurídica orientada a la satisfacción de un fin fundacional de interés general, empleando para ello una actividad y organización de naturaleza eminentemente empresarial, y aceptando también con ello, en principio, los riesgos y beneficios que puedan derivarse de su ejercicio ${ }^{18}$. La caja de ahorros ha procurado siempre la realización de un fin social a través de su actividad crediticia, cuyo ejercicio permitía la realización del fin benéfico originario de la institución al que se encontraba completamente subordinada. La actividad económica, concesión de crédito en condiciones ventajosas a las clases menesterosas y propagación del ahorro, representaba en sí misma el fin de la entidad. Su importancia progresiva la ha elevado, no obstante, a un primer plano, variando significativamente los fines sociales a que atiende la entidad, pero sin que ello sea razón suficiente para anular sin más su naturaleza fundacional.

De ahí que sea aún más sorprendente la postura del Tribunal Constitucional español, en su Sentencia 49/1988, de 22 de marzo, al no

18 La fundación-empresa cobra fuerza en nuestro ordenamiento no sólo por los resultados de la experiencia internacional de países como Alemania o Estados Unidos, en donde ha dejado de ser una desconocida, sino también por la propia doctrina y legislación española que van reconociendo cada vez con mayor naturalidad las implicaciones económicas de la actividad fundacional. Sobre la teoría de la fundación-empresa en el Derecho español, su concepto, clases y reconocimiento normativo en la evolución legislativa española, vid. Anabelén Casares Marcos (2003: 385 y ss.) y la doctrina allí citada. 
admitir la calificación de las cajas como fundación-empresa en nuestro ordenamiento jurídico por el "cambio cualitativo" experimentado por su inicial actividad crediticia, mostrando, eso sí, su más profunda desconfianza ante la idea misma de la fundación-empresa, a la que considera "una de tantas importaciones de la doctrina alemana que se han realizado o se intentan realizar en nuestro derecho".

Se fortalece e intensifica, a resultas de ello, la intromisión pública en la actuación de estas entidades eminentemente privadas, que pasan así a estar supeditadas al cumplimiento en muchas ocasiones de objetivos e intereses propiamente políticos, sin que los poderes públicos asuman, no obstante, la más mínima responsabilidad por las decisiones de aquella naturaleza que pudieran no respetar criterios de racionalidad económica y pesar negativamente en los resultados finales de la entidad ${ }^{19}$.

La doctrina del Tribunal Constitucional ignora, en definitiva, con su rechazo a la calificación de las cajas como fundación-empresa, la doble vía en que se materializa hoy día su función social, ya que si bien es cierto que la obra benéfico social es su exponente más importante, por cuanto implica el destino de una parte de sus beneficios empresariales a un fin de interés general, no cabe olvidar que la forma en que las cajas realizan su actividad crediticia tiene también un significado social innegable, aunque haya experimentado, lógicamente, modificaciones desde sus orígenes $^{20}$.

Su fin inicial de promoción del ahorro continúa vigente, si bien adaptado a las condiciones socioeconómicas actuales ${ }^{21}$. Las cajas movilizan el ahorro y son responsables, en buena medida, de la escasa

19 Sobre la intervención de los poderes públicos en las cajas de ahorros, mucho más intensa en estas entidades que en el resto de las entidades de crédito, vid. Anabelén Casares Marcos (2003: 545 y ss.) y la doctrina allí citada.

20 Además de la aportación de las cajas a la obra benéfico social, asociada a la aplicación del beneficio neto, destaca su contribución a la estabilidad del sistema financiero y a la generación de beneficios sociales derivados del desarrollo de su actividad financiera, entre los que cabe citar especialmente su participación en el logro de una mayor eficiencia, tanto de mercado como productiva, así como en la reducción de la exclusión financiera y en la financiación de actividades de sensibilidad social. Vid., en este sentido, Victorio Valle Sánchez (2004: 281 y ss.) y Enrique Castelló Muñoz (2004: 287) para quien las cajas de ahorros "son, hoy por hoy, la primera fuerza en el suministro de bienes sociales, después del sector público español. Y principal referente del llamado «tercer sector»".

21 Para José Luis García Delgado (Director), Juan Carlos Jiménez, Javier Sáez Fernández y Enrique Viaña (2004: 137) no cabe duda que "la lucha contra la usura que está en el origen de las cajas de ahorros se troca hoy en aumento de la competencia bancaria", pues con ellas se combaten las "pulsiones oligopolistas" del sistema bancario. 
repercusión que tiene en nuestro país el fenómeno de la exclusión financiera, ya que hacen accesible la intermediación financiera a todas las capas sociales, destacando especialmente la atención tanto a colectivos excluidos, especialmente grupos de rentas bajas o inmigrantes, mediante el crédito pignoraticio concedido por sus montes de piedad o el microcrédito, como a todas las zonas geográficas de su ámbito territorial de actuación ${ }^{22}$. Se trata de una de las manifestaciones más importantes de la función social de su actividad económica, sobre todo si se toman en consideración las consecuencias de la exclusión financiera de ciertas capas de la población en algunos países europeos, fundamentalmente el Reino Unido, donde las cajas de ahorros han perdido su naturaleza y funciones tradicionales a resultas de su evolución y proceso de transformación societaria ${ }^{23}$.

III. DESAFÍOS INSTITUCIONALES DE LAS CAJAS DE AHORROS ESPAÑOLAS A LA LUZ DE LAS RECIENTES MODIFICACIONES DE LA LEGISLACIÓN FINANCIERA: LEYES 44/2002, DE 22 DE NOVIEMBRE, DE MEDIDAS DE REFORMA DEL SISTEMA FINANCIERO, Y 26/2003, DE 17 DE JULIO, DE TRANSPARENCIA ${ }^{24}$

La evolución histórica de las cajas de ahorros españolas, apuntada supra, deja constancia de la peculiaridad que ha acompañado desde siempre a la institución. Surgidas en un marco de gran autonomía, fueron adaptando su actividad social a las condiciones socioeconómicas

22 CECA (2003) recoge el porcentaje de municipios "rescatados" por las entidades de crédito españolas al garantizar con su sola presencia la existencia de servicios financieros mínimos. En este sentido, los bancos privados rescataron de la exclusión al 1,25 por 100 de los municipios españoles y las cooperativas de crédito al 3,45 por 100, frente al 13,40 por 100 de las cajas de ahorros, lo que supone un 3,45 por 100 de la población sobre el 4,95 por 100 total rescatado por las entidades de crédito en su conjunto. A estos datos cuantitativos añade Juan Ramón Quintás Seoane (2003: 17 y ss.) un dato cualitativo asociado a su papel en la inclusión financiera como manifestación del capital social, ya que la actividad financiera desarrollada en estos municipios suele ir aparejada al desarrollo individual o colectivo de iniciativas para la comunidad. Insiste en ello, analizando la atención de las cajas de ahorros españolas a la exclusión financiera desde su nacimiento y a lo largo de su evolución histórica, en (2004: 268 y ss.). Vid., asimismo, Santiago Carbó Valverde y Rafael López del Paso (2002: 79 y ss.). (1999)

23 Así lo denuncia el Informe Rowntree, realizado por E. Kempson y C. Whyley

24 Si bien su denominación oficial es Ley 26/2003, de 17 de julio, por la que se modifican la Ley 24/1988, de 28 de julio, del Mercado de Valores, y el Texto Refundido de la Ley de Sociedades Anónimas, aprobado por el Real Decreto Legislativo 1564/1989, de 22 de diciembre, con el fin de reforzar la transparencia de las sociedades anónimas cotizadas, es conocida en el ámbito financiero como Ley de Transparencia. Asimismo, la Ley 44/2002, de 22 de noviembre, es conocida también como Ley Financiera. 
imperantes en cada momento y a una legislación que procuraba por todos los medios uniformar, en un principio, su naturaleza y caracteres básicos y garantizar, con posterioridad, la representatividad, participación y democracia en sus órganos de gobierno.

A pesar de todo ello, la naturaleza y función originarias para las que fueron creadas sufrirían pocos cambios, al menos en su esencia; así lo avala su articulación temprana como instrumentos para la satisfacción de un fin social a través del ejercicio de una actividad crediticia. Presentan desde sus comienzos una doble vertiente fundacional y empresarial, siendo así que el nacimiento de las cajas al margen de cualquier normativa preestablecida explica el particularismo estatutario que dio origen a unas entidades que, sin pretenderlo, tuvieron como rasgo común su identificación con lo que posteriormente daría en denominarse como fundación-empresa.

El silencio posterior del ordenamiento jurídico español respecto a su naturaleza jurídica, sancionado por el propio Tribunal Constitucional, está en la base de la decidida colonización política de su organización y funcionamiento. La reforma de 1977, en la que profundiza la LORCA de 1985, consagra la presencia de los poderes públicos en los órganos de gobierno de las cajas de ahorros dada su condición de "entes sociales"; una tendencia seguida también por la legislación autonómica dictada con posterioridad.

El propio éxito económico de la institución ha puesto a la caja de ahorros en el punto de mira de los poderes públicos y ha acelerado el proceso de su politización, desembocando, finalmente, en el debate sobre extremos tales como la conveniencia de su posible privatización, la viabilidad de su fusión para la constitución de una gran caja regional o los beneficios que derivarían de la aplicación de sus beneficios a actividades e inversiones de interés regional ${ }^{25}$. Esta situación y los vientos de reforma que han azotado a la mayor parte de las cajas de ahorros europeas en las últimas décadas, han acabado por encender también en nuestro país la mecha de la reforma, dando lugar a un encarnizado debate entre las

25 Son muchos los temas polémicos en relación a las cajas de ahorros sobre los que se ha debatido en los últimos tiempos. José Antonio Antón Pérez (1998: 187) concluye, en concreto, a la vista de la situación actual de las cajas y de su intervención por los poderes públicos, que la entidad reclama la "neta separación de los aspectos empresarial y benéfico". Sólo así se permitiría una "más clara especialización del trabajo" y una "mayor independencia en la fijación de objetivos" en cada uno de los dos sectores de actividad. 
diversas posturas políticas en la materia, que ha acabado por cristalizar en los artículos 8 y 14 de la que ya se conoce como Ley Financiera, de 22 de noviembre de 2002 .

1. La intervención pública en los órganos de gobierno de las cajas de ahorros y el fantasma de su politización

La modificación de la organización de las cajas de ahorros que introduce la reforma Fuentes Quintana en 1977 es el primer paso de un largo proceso de progresiva politización de la estructura interna de estas entidades crediticias $^{26}$. Es opinión comúnmente admitida que su gestión corresponde, en la sombra, a los poderes públicos, especialmente tras las elevadas cotas de presencia pública que han llegado a reflejar sus órganos de gobierno como consecuencia de la aprobación de la LORCA y de su desarrollo autonómico. Actualmente participan en su administración y gobierno representantes públicos de las Comunidades Autónomas y de las corporaciones locales vinculadas al ámbito de actuación de la entidad, a lo que es preciso sumar, además, la representación de las entidades fundadoras, en aquellos casos en que hayan sido poderes públicos.

El anhelo de la LORCA por materializar en su seno una estructura democrática y representativa se escuda, fundamentalmente, en el principio de participación y en la interacción Estado-sociedad que consagra el texto constitucional español, por lo que ha sido calificado de básico por el Tribunal Constitucional. Las Comunidades Autónomas pueden, en consecuencia, especificar y desarrollar las bases de esa organización, sin llegar, en ningún caso, a anularlas.

Los pilares sobre los que se asienta la organización interna de la caja de ahorros están establecidos en el artículo 1 de la LORCA, que confía su "administración, gestión, representación y control" a tres órganos de gobierno, la Asamblea General, el Consejo de Administración y la Comisión de Control, cuyos miembros ejercen sus funciones "en beneficio exclusivo de los intereses de la Caja a que pertenezcan y del

26 Fernando Garrido Falla (1977: XX) se mostró muy crítico con la nueva organización de las cajas a raíz de la controversia originada por la reforma de 1977, al entender que ésta "entra a saco" en su organización. Para el autor no cabe duda que el dilema jurídico planteado en ese momento por el Decreto 2290/1977 exigía concluir o bien su ilegalidad o bien que la naturaleza jurídica de las cajas no respondía exactamente al esquema fundacional entonces vigente del artículo 37 del Código civil. 
cumplimiento de su función social"27. En ellos la "representación de los intereses colectivos" queda asegurada mediante la participación de diversos estamentos, entre los que deben figurar, al menos, las corporaciones municipales en cuyo término tenga abierta oficina la caja de ahorros, sus impositores, las personas o entidades fundadoras de la misma y, por último, sus empleados ${ }^{28}$.

La Sentencia 49/1988 del Tribunal Constitucional sancionó la participación de las Comunidades Autónomas en la definición de esta estructura al declarar no básico el reparto porcentual que establece el artículo 2 de la LORCA. Las leyes autonómicas de desarrollo han procedido, en consecuencia, a adaptar los porcentajes fijados en la Ley estatal e incluso los estamentos concretos que alcanzan representación en la Asamblea, a sus particularidades territoriales específicas. Cabe apreciar, en este sentido, una tendencia cada vez más acentuada a dar entrada en los órganos de gobierno de la caja a representantes de los intereses autonómicos, en un intento claro por vincular una parte de los resultados económicos de la entidad a la región cuyo ahorro y recursos capta en el ejercicio de su actividad crediticia ${ }^{29}$. Se acrecienta así el riesgo de "politizar" en exceso la entidad a raíz de su identificación como "ente social", permitiendo incluso, en última instancia, su utilización partidista al abrigo de su función social.

Esta tendencia, constante y continua, a aumentar la presencia pública en las cajas contribuyó a enmarañar aún más una situación bastante compleja de por sí y deliberadamente equívoca. Las cajas de ahorros españolas son consideradas y definidas legalmente como entidades privadas a todos los efectos, una calificación dudosa, sin embargo, desde los postulados de la normativa comunitaria y, especialmente, de la Directiva 80/723/CEE, de la Comisión, de 25 de junio de 1980, relativa a la transparencia de las relaciones financieras entre los Estados miembros

27 A ellos se suman, por mandato de la Ley 26/2003, de 17 de julio, dos nuevas Comisiones, de Retribuciones y de Inversiones, constituidas en el seno del Consejo de Administración de la caja de ahorros conforme a los artículos 20 bis y 20 ter adicionados a la LORCA.

28 Estos estamentos participan en la Asamblea General de la caja de ahorros, en virtud del artículo 2.3 de la LORCA, y en el Consejo de Administración y Comisión de Control, conforme a los artículos 13.2 y 22.1 de la LORCA. Así lo recoge también la normativa autonómica de desarrollo dictada en la materia.

29 María Teresa Martínez Martínez (2002: 45) habla, en este sentido, de la lucha mantenida por las administraciones públicas para asegurarse "la captación y el dirigismo" de las cajas, así como su "estrecha vinculación" con el ámbito territorial (municipal o regional) en el que operan. 
y las empresas públicas, así como a la transparencia financiera de determinadas empresas.

El concepto europeo de empresa pública que recoge esta Directiva representa una amenaza para las cajas españolas en la medida en que parte, fundamentalmente, de la apreciación de la realidad misma existente en el mercado y no de consideraciones puramente formales. Así lo refleja el Preámbulo de la Directiva citada, al subrayar expresamente que:

los poderes públicos pueden ejercer una influencia dominante sobre el comportamiento de las empresas públicas, no sólo en el caso de que sean propietarios o posean una participación mayoritaria en dichas empresas, sino también debido a los poderes que posean en sus órganos de gestión o vigilancia, bien por sus estatutos, bien por el reparto de las acciones.

Es por esta razón que su artículo 2.1 b) considera pública a "cualquier empresa en la que los poderes públicos puedan ejercer, directa o indirectamente, una influencia dominante en razón de la propiedad, de la participación financiera o de las normas que la rigen", sentando en su párrafo 2 la presunción de que existe este tipo de dominio:

cuando, en relación con una empresa, el Estado u otras administraciones territoriales, directa o indirectamente: posean la mayoría del capital suscrito de la empresa; o dispongan de la mayoría de los votos correspondientes a las participaciones emitidas por la empresa; o puedan designar a más de la mitad de los miembros del órgano de administración, de dirección o de vigilancia de la empresa ${ }^{30}$.

La creciente preocupación por las posibles repercusiones de esta normativa comunitaria en la organización y régimen de gobierno de

30 Se trata de una cuestión que ha suscitado gran preocupación en el ámbito comunitario, motivando la presentación al respecto de diversas preguntas a la Comisión. Destacan, en este sentido, las preguntas de José Barros Moura sobre la Caixa Economica Faialense (Diario Oficial núm. C 195, de 31 de julio de 1989), de Carlos Robles Piquer sobre la regulación de las actividades de las cajas en la legislación financiera comunitaria (Diario Oficial núm. C 248, de 23 de septiembre de 1991), de Gerardo Fernández-Albor sobre la vulnerabilidad de las cajas ante el mercado único (Diario Oficial núm. C 323, de 13 de diciembre de 1991) y de Salvador Garriga Polledo relativa a las consideraciones comunitarias sobre las cajas (Diario Oficial núm. $28 \mathrm{E}$, de 6 de febrero de 2003). Sobre el concepto de empresa pública y las ayudas prohibidas por el Derecho comunitario de la competencia desde la perspectiva de las cajas de ahorros españolas, vid. Juan Antonio Ureña Salcedo (2002). 
las cajas de ahorros españolas -entre otras, la consideración eventual de algunos de sus créditos como auténticas ayudas públicas-, ha propiciado el acercamiento de las diversas posturas políticas existentes en esta materia al objeto de limitar la presencia pública en el seno de la institución hasta un 50 por 100 del total de los derechos de voto en sus órganos de gobierno, allanando el camino a la modificación operada finalmente en tal sentido por la Ley Financiera ${ }^{31}$.

Independientemente de la reforma de 2002, y del porcentaje concreto que corresponda en cada caso a la representación pública en su seno, la regulación vigente del sistema de gobierno de estas entidades crediticias, apenas modificado en algunos detalles concretos, no permite sino certificar la transferencia real y efectiva al ámbito público del poder de decisión en su gestión y administración actual ${ }^{32}$.

Aunque nominalmente la representación de los poderes públicos no exceda en ningún caso del 50 por 100 de los votos totales en sus órganos de gobierno, no cabe duda alguna, dada la imbricación de intereses políticos en otros sectores con representación en las cajas, que la situación anterior apenas sufre modificación. Pervive, en suma, la pugna política por hacerse con el control de la actividad económica de estas entidades, o conservarlo en su caso, y por decidir el destino de una parte esencial de sus excedentes ${ }^{33}$. Continúa latente, por tanto, la amenaza de sanción comunitaria por incumplimiento del Derecho europeo de la competencia y, en particular, de las ayudas públicas, siendo éste uno de

31 Su artículo 8, apartado segundo, dota de nueva redacción al artículo 2.3 de la LORCA, que establece ahora que "la representación de las Administraciones públicas y entidades y corporaciones de derecho público en sus órganos de gobierno, incluida la que corresponda a la entidad fundadora cuando ésta tenga la misma naturaleza, no podrá superar en su conjunto el 50 por 100 del total de los derechos de voto en cada uno de tales órganos, teniendo que estar representadas todas las entidades y corporaciones". Su carácter básico, conforme a la modificación operada asimismo en la Disposición final cuarta de la LORCA, deja cierto margen de actuación a las Comunidades Autónomas que podrán ampliar el número de grupos representados y concretar los diversos porcentajes de representación si bien respetando ese techo máximo del 50 por 100 de presencia pública.

32 Así lo sostiene también Heike Mai (2004: 13 y ss.) para quien el objetivo de reducir la presencia pública en las cajas no ha sido logrado en absoluto por la Ley Financiera de 2002 que consagra, por el contrario, la influencia política sobre las decisiones económicas de la entidad.

33 La caja de ahorros se encuentra inmersa actualmente en una dinámica en la que el cambio de gobierno o de partido político puede provocar, y en ocasiones provoca, cambios importantes en la política económica y en los objetivos perseguidos por la entidad. Vid. María José Vañó Vañó (2000 b: 603 y ss.). No es probable que la Ley Financiera termine con esta situación, de ahí que la reforma de 2002 haya sido calificada de "decepcionante" por Juan Sánchez-Calero Guilarte (2003: 432) en la medida en que refleja tan sólo el interés del legislador estatal o autonómico "por regular el poder en las cajas". 
los retos más importantes a que tendrá que hacer frente el futuro de la entidad, obligada a adoptar cotas cada vez mayores de profesionalidad, racionalidad y eficiencia económica si desea conjurar el peligro ${ }^{34}$.

\section{La ampliación de los recursos propios de las cajas y el} fantasma de su privatización: las cuotas participativas

La identidad tradicional de las cajas de ahorros españolas se encuentra en entredicho no sólo por el riesgo de una excesiva politización de sus órganos de gobierno, y posible consideración, por tanto, como empresa pública desde la perspectiva de la normativa comunitaria, sino también por el peligro de que sigan la senda abierta por otras cajas europeas y se transformen, finalmente, en sociedades privadas. Su naturaleza es ya de por sí privada, si bien el fenómeno de privatización a que se alude aquí hace referencia a la atribución de derechos de propiedad sobre su activo patrimonial a titulares concretos e individualizables.

Las cajas de ahorros se enfrentan así a una situación paradójica, en la medida en que su éxito económico puede acabar definitivamente con su concepción originaria. La desaparición de las barreras normativas existentes entre los diversos tipos de entidades crediticias y financieras, las abocó a una mayor competitividad, a lo que se sumó poco después la necesidad de fortalecer sus recursos propios a resultas de las exigencias de la normativa comunitaria ${ }^{35}$. Sin embargo, a

34 Como ha quedado demostrado, recientemente, con el rechazo de la Comisión europea a la entrada de las cajas de ahorros españolas en la composición accionarial diseñada para reflotar la parte civil de los astilleros públicos Izar, al considerar que el control por parte de la SEPI del 49 por 100 de la sociedad civil y por las cajas del 20 por 100 daría como resultado una estructura empresarial controlada mayoritariamente por entidades públicas. Ya en el año 2000 se presentó ante el Comisario europeo de competencia una denuncia cuestionando un préstamo de Caja Cantabria a SNIACE por considerar que se trataba de una subvención, dado el carácter público de la caja. Si bien se logró reconducir la situación en aquel momento, lo cierto es que existe un precedente que juega en contra de las cajas españolas. Se trata de la Sentencia del Tribunal de Primera Instancia de 12 de diciembre de 1996, desestimatoria del recurso de la compañía aérea Air France contra la Decisión 94/662/CE, de la Comisión Europea, contraria a la suscripción de obligaciones de la compañía por la caja francesa Caisse des Dépôts et consignations-participations. José Juan Franch Meneu (2000: 39) pone el dedo en la llaga al afirmar que, una vez desaparecida la banca pública, "renace la banca pública autonómica y local a través de las cajas de ahorro cuya titularidad jurídica no está nada clara", lo que comporta una serie de amenazas importantes para la competencia, la eficiencia del sistema financiero y el desarrollo económico.

35 Víctor E. Barrios (2003: 267 y ss.) analiza los factores explicativos de la fijación del cociente de capital de las cajas de ahorros. Con este propósito, se hace eco de las posturas enfrentadas acerca de la conveniencia de una regulación, estricta y efectiva, de requisitos mínimos de capital sobre activos, así como del impacto sobre las cajas de la revisión en profundidad del Acuerdo de Basilea de 1988. En las nuevas recomendaciones del Comité continúa ocupando un 
diferencia de los bancos y de las restantes entidades financieras, las cajas carecen, por su naturaleza fundacional, de capital en sentido estricto y, por tanto, de mecanismos que les permitan allegar fondos externos para reforzar su solvencia.

Si bien es cierto que el nivel de solvencia de estas entidades en España ha sido tradicionalmente muy superior al de las cajas de ahorros europeas, es preciso tomar en consideración este aspecto de su concepción empresarial y crediticia con el objeto de conjugar la posible necesidad de una ampliación de capital de la caja con su vertiente fundacional y vocación social íntrinseca, de forma que su crecimiento, expansión y consolidación en los mercados financieros no afecte en demasía a los fondos que proveen a la realización de su fin de interés general.

Las diversas soluciones que se han arbitrado en el ámbito europeo para atajar el problema pueden ser clasificadas en función de su mayor o menor impacto sobre la naturaleza y configuración institucional de la entidad, optando nuestro ordenamiento jurídico por aquellas posiciones intermedias que buscan incrementar los recursos propios de las cajas preservando su identidad tradicional.

De esta forma, las cajas españolas cuentan en la actualidad con tres tipos de instrumentos diversos para satisfacer el aumento de sus recursos de capital. De un lado, la autofinanciación, propiciada por el Banco de España pero que opera en detrimento de la cantidad destinada a inversión en obra social ${ }^{36}$. De otro lado, la emisión de deuda subordinada, regulada por primera vez en 1985 abriendo a las cajas la posibilidad de acceder a fondos externos ${ }^{37}$. $Y$ finalmente, el recurso a las cuotas

lugar esencial el requisito de capital mínimo como instrumento regulador fundamental, si bien destacando las actividades de inspección supervisora y disciplina del mercado y otorgando un lugar primordial tanto a las agencias de rating externo como a los sistemas de rating interno. Vid., asimismo, Fernando Pampillón (2004: 321 y ss.).

36 Si con anterioridad el artículo 11.4 de la Ley $13 / 1985$, de 25 de mayo, de inversiones obligatorias, recursos propios y obligaciones de información de los intermediarios financieros, obligaba a las cajas a destinar a reservas, o a fondos de provisión no imputables a riesgos específicos, un 50 por 100, como mínimo, de sus excedentes líquidos, ahora, tras la modificación operada en su enunciado por la Ley 44/2002, de 22 de noviembre, toma en consideración los derechos económicos de los titulares de las cuotas participativas, cifrando esta cantidad en un 50 por 100, como mínimo, de aquella parte de los excedentes de libre disposición que no sea atribuible a los cuotapartícipes. El Banco de España tiene la facultad de reducir este porcentaje si los recursos propios superan en más de un tercio los mínimos establecidos.

37 Su insuficiencia manifiesta para hacer frente a las exigencias de fortalecimiento de los recursos propios de las cajas de ahorros motivaría su reforma en 1992 y la adopción de un nuevo instrumento, las cuotas participativas, ensayado con éxito en otros ordenamientos comparados. Sobre las limitaciones de la deuda subordinada de las cajas y su comparación con las cuotas participativas, vid. Alberto Javier Tapia Hermida (1991: 708 y ss.). 
participativas, equivalentes en el plano económico a las acciones de las sociedades anónimas pero sin los derechos políticos que confieren estas últimas. Cada una de estas opciones cuenta con restricciones evidentes, destacando especialmente, por su reciente reforma, trascendencia e impacto sobre la configuración de la caja, la cuota participativa.

Recogida en nuestro ordenamiento jurídico por primera vez en la LDIEC de 1988, surge para hacer frente a las dificultades mal o poco atendidas por la deuda subordinada, que se reveló incapaz de hacer frente a las demandas de capitalización de las cajas en un entorno cada vez más competitivo y global. Comparte con la entidad que la emite la dificultad de precisar su naturaleza jurídica, ya que se trata de una figura a medio camino entre la deuda subordinada y la acción propia de las sociedades anónimas, si bien se diferencia de esta última en que computan como recursos propios de forma diferente: recurso propio de segunda categoría en el caso de la cuota participativa y recurso propio básico en el supuesto de la acción.

Profundiza en ello el Real Decreto 664/1990, de 25 de mayo, sobre cuotas participativas de las cajas de ahorros, al ofrecer a su titular una pléyade de derechos económicos, privándole, sin embargo, de cualquier tipo de derecho político, representatividad o mera información en el seno de la entidad ${ }^{38}$. Se ha atribuido precisamente a este régimen jurídico de la cuota el silencio y la inactividad posterior de las cajas, que si bien habían reclamado con insistencia su regulación, no acudieron después, como se esperaba, a su pronta emisión mostrando una cierta indiferencia ante este título ${ }^{39}$.

Qué duda cabe que el debate suscitado en torno a la conveniencia de reconocer alguno de estos derechos a las cuotas participativas está vinculado a una cuestión de mayor calado, como es la de las posibles limitaciones y condicionantes a imponer normativamente a sus adquirentes en orden a preservar la naturaleza jurídica de la caja de

38 Sobre el régimen jurídico de la cuota participativa derivado de la LDIEC de 1988 y del Real Decreto 664/1990, vid., por todos, Anabelén Casares Marcos (2003: 492 y ss.) y la doctrina allí citada; Marta García Mandaloniz (2003: 296 y ss.); María Pilar Gómez Jiménez (1999: 4291 y ss.) y, Francisco José Valero y Sergio Esteban Crespo (2000), in toto.

39 Se produjo una única emisión excepcional por parte de la CECA en 1988 en los casi quince años transcurridos desde la creación legislativa de este instrumento financiero hasta su modificación por la Ley Financiera en 2002. Para Marta García Mandaloniz (2003: 301), si bien la falta de emisiones podría deberse a la insuficiente concreción de su régimen jurídico, "lo cierto es que sin oferta no puede haber demanda". 
ahorros y evitar su posterior transformación en sociedad anónima. No cabe olvidar que la experiencia comparada ha demostrado que por muchas que sean las limitaciones establecidas en cuanto a sus potenciales adquirentes o al porcentaje de que puedan ser titulares, antes o después, directa o indirectamente, la titularidad de las cuotas participativas se concentra en manos de unos pocos inversores, que acaban por integrar grupos de presión favorables a su transformación en acciones.

Son estos temores los que han llevado a la doctrina a proponer diversas vías intermedias para facilitar la emisión y colocación de las cuotas participativas, así como el aumento consiguiente de los recursos propios de la entidad sin que ello afecte a la conservación de su identidad y naturaleza jurídica originarias. Una de las ideas más reiteradas, en este sentido, es la de la colaboración e interrelación de las cajas de ahorros, reivindicándose fundamentalmente el papel que corresponde en esta materia a la Confederación Española de Cajas de Ahorros (CECA) ${ }^{40}$.

La Ley 44/2002, de 22 de noviembre, ha supuesto, en cualquier caso, un impulso y desarrollo en profundidad del régimen jurídico de la cuota participativa en nuestro ordenamiento. En su artículo 14 da nueva redacción al artículo 7 de la Ley 13/1985, de 25 de mayo, e insiste en la ausencia de derechos políticos para sus titulares, si bien admite la creación de un síndicato de cuotapartícipes cuyo Presidente podrá asistir a las Asambleas Generales con voz y sin voto ${ }^{41}$. Establece, asimismo, ciertas cortapisas y salvaguardas orientadas a evitar la entrada masiva de capital privado en las cajas y el riesgo de traslación consiguiente del núcleo de decisión en la entidad a cuotapartícipes concretos y determinados.

Su desarrollo reglamentario se produce por Real Decreto 302/2004, de 20 de febrero, sobre cuotas participativas de las cajas de ahorros, cuyo Preámbulo subraya ya las diferencias más significativas respecto al marco jurídico anterior, establecido en la Disposición adicional $12 .^{a}$ de la LDIEC y en el Real Decreto 664/1990, al que tilda de insuficiente en la medida en que "no ha permitido el desarrollo efectivo de este instrumento, concebido como una fórmula para paliar las dificultades de captación de recursos propios básicos por parte de las cajas de ahorros".

40 A título de ejemplo, Francisco Moraleda García de los Huertos (2003: 147 y ss.).

41 Alberto Javier Tapia Hermida (2003: 498) se refiere al "efecto balsámico" que tuvo la supresión de todo derecho político de los cuotapartícipes durante la tramitación parlamentaria de la Ley. 
Es más, justifica la iniciativa del legislador en el artículo 14 de la Ley Financiera, "por la constatación de que la utilización de las cuotas participativas por parte de las cajas de ahorros ha sido prácticamente nula, impidiendo que se alcancen los objetivos que perseguía su creación" ${ }^{42}$.

Tanto el Real Decreto 302/2004 como el artículo 14 de la Ley 44/2002, de la que trae causa, representan un avance significativo respecto a la normativa anteriormente vigente en la materia, en la medida en que detallan con suficiente claridad y con mayor seguridad jurídica las exigencias técnicas y jurídicas para la emisión efectiva de cuotas participativas por las cajas de ahorros españolas, sin que hayan logrado conjurar del todo, sin embargo, el fantasma de una posible transformación de estas entidades en sociedades mercantiles ${ }^{43}$.

En cualquier caso, la nueva regulación de la cuota participativa persigue tanto un efecto directo, cual es la ampliación de las posibilidades de financiación de las cajas de ahorros mediante recursos propios básicos, como otro indirecto, al abrir la entidad a la evaluación de su gestión por el mercado de valores ${ }^{44}$. Entiendo, en consecuencia, que si se quiere asegurar el éxito de la cuota participativa y no perjudicar el valor económico ni el interés general de la caja, hay que profundizar decididamente en la desvinculación de su actuación económica de toda connotación política, garantizando la autonomía de cada una de las dos vertientes presentes en la entidad, al objeto de lograr una mayor rentabilidad y una gestión más eficiente de su legado social. De ahí, quizá, algunas de las medidas adoptadas recientemente para reforzar la transparencia y el buen gobierno en el ámbito de las cajas de ahorros.

42 Pese a ello, Francisco José Valero y Alfonso García Mora (2004: 77) auguran un futuro inmediato de cierta inactividad por parte de las cajas de ahorros que no acudirían a una utilización masiva de las cuotas participativas, al menos al principio, siendo previsible un "efecto bola de nieve, que hará que las primeras emisiones faciliten la realización de las siguientes, no necesariamente por las mismas entidades". Sostienen por ello que, tras la aprobación de la normativa aplicable, se abre ahora un período de "desarrollo de metodologías de valoración adaptadas a las características específicas de las cajas de ahorros españolas, tanto desde el punto de vista institucional como de las particularidades concretas de su negocio".

43 Para una valoración en profundidad del contenido e impacto de esta nueva regulación en la configuración tradicional de las cajas de ahorros españolas, vid. Anabelén Casares Marcos (2005).

44 Alberto Javier Tapia Hermida (2003: 479). 


\section{Las cajas de ahorros y el «buen gobierno corporativo»}

Asistimos en los últimos años a un auge espectacular del debate sobre la necesidad de adoptar medidas adecuadas para garantizar un buen "gobierno corporativo", expresión adoptada en España como consecuencia de la traducción literal del término anglosajón corporate governance. Los escándalos que han sacudido recientemente a los mercados financieros internacionales han desatado, en definitiva, la preocupación por las implicaciones éticas de las decisiones económicas adoptadas en el ámbito de la empresa, incluyendo en ésta, naturalmente, a las entidades bancarias y crediticias.

Las reglas de gobierno corporativo pretenden pautar, en este contexto, tanto las relaciones internas como la proyección exterior de la empresa en sus contactos con las Administraciones públicas, con otras empresas, con los consumidores y usuarios, así como con la sociedad en general ${ }^{45}$. Surgen, originariamente, en defensa de los accionistas minoritarios y de los acreedores de la sociedad, esto es, de quienes aportan el capital, con el claro propósito de separar propiedad y gestión. Su evolución, no obstante, ha abierto el gobierno corporativo a otros ámbitos. La necesidad de delimitar claramente los derechos y obligaciones de las partes involucradas, esto es, propietarios, directores, administradores, accionistas y empleados, ha desembocado en la formulación de principios y reglas concretas a respetar en el proceso de toma de decisiones empresariales. Es así como el debate sobre el gobierno corporativo ha acabado por centrarse en la promoción de la transparencia, equidad y responsabilidad social de las empresas ${ }^{46}$.

45 Sobre la expansión del Derecho en la reglamentación de las conductas humanas en el mundo económico, vid. Jesús González Pérez (2002: 422 y ss.). Vid., asimismo, el documento de trabajo del Círculo de Empresarios, El gobierno de las sociedades cotizadas, de 14 de noviembre de 2002, que cifra en tres los pilares sobre los que debe asentarse el gobierno de las sociedades, concretamente, el cumplimiento de las normas establecidas, y voluntariamente asumidas, el principio de transparencia y la autorregulación.

46 Dando lugar con ello a diferentes corrientes entre los economistas a la hora de abordar los problemas de gobierno empresarial, según se tenga en cuenta tan sólo al accionista o shareholder o se amplíe el análisis a los stakeholders. Sobre su evolución e implicaciones actuales, vid. el número extraordinario sobre corporate governance de Análisis Financiero (2003); el monográfico sobre el gobierno de la empresa de Boletín de Estudios Económicos (2004); Enrique Castelló Muñoz (2004: 282 y ss.); Rafel Crespí Cladera y Miguel Á. García Cestona (2004: 176 y ss.) y Pontus Hallengren (2005: 49 y ss.). Asimismo, son de gran interés el Libro Verde de la Comisión de las Comunidades Europeas, de 18 de julio de 2001, para fomentar un marco europeo para la responsabilidad social de las empresas y la Comunicación de la Comisión, de 2 de julio de 2002, relativa a la responsabilidad social de las empresas: una contribución empresarial al desarrollo sostenible. 
Estas prácticas tienen también una importancia indudable en el ámbito de las entidades financieras y crediticias, en cuanto que éstas no sólo tutelan el dinero de sus accionistas sino también el de terceros ajenos a su propiedad. Son una pieza esencial para el crecimiento económico y social tanto en el ámbito nacional como internacional. De ahí que el interés del gobierno corporativo en estas entidades se manifieste desde una triple perspectiva, económica, social y financiera ${ }^{47}$.

En España esta tendencia ha cristalizado finalmente en la Ley 26/2003, de 17 de julio, que trae causa, a su vez, de las recomendaciones recogidas en los Informes Olivencia sobre el bueno gobierno de las sociedades, de febrero de 1998, y Aldama para el fomento de la transparencia y seguridad en los mercados y en las sociedades cotizadas, de enero de $2003^{48}$. Aunque está dirigida, en un principio, a aquellas empresas que cotizan en los mercados financieros, las Disposiciones adicionales $2 .^{\mathrm{a}}$ y $4 .^{\mathrm{a}}$ se refieren, en particular, a las cajas de ahorros.

Si bien es cierto que no existen en ellas títulos de propiedad, el propio Informe Olivencia sostiene, en este sentido, que:

el hecho de que las recomendaciones del Código tengan como primeras destinatarias a las sociedades que cotizan en mercados de valores $y$, en especial, a las que presentan un mayor porcentaje de acciones de libre circulación (capital flotante), no significa que sólo sean útiles para estas sociedades ${ }^{49}$.

47 Juan A. Maroto y Mónica Melle (2001: 162) desarrollan esta triple perspectiva, subrayando cómo el interés económico "coincide con el de cualquier empresa no financiera" por la "maximización de la riqueza de los accionistas", mientras que el punto de vista social es más importante que en otras empresas "debido a que la intermediación financiera que les es propia incide sobre un mayor número de grupos de interés, así como sobre la sociedad en su conjunto", considerando desde la última perspectiva, en fin, "la importancia de sus efectos, reales o potenciales, sobre la solvencia del sistema financiero en su conjunto".

48 España se adelanta así en el tiempo al Informe Winter relativo a un marco normativo moderno para el Derecho de sociedades en Europa, presentado el 4 de noviembre de 2002 por un grupo de alto nivel de expertos en Derecho de sociedades designado por el Comisario Bolkestein en septiembre de 2001, y al que da respuesta la Comunicación de la Comisión al Consejo y al Parlamento Europeo, de 21 de mayo de 2003, sobre la modernización del Derecho de sociedades y mejora de la gobernanza empresarial en la Unión Europea: un plan para avanzar.

49 Juan Antonio Maroto Acín (1999: 207) no duda en defender la aplicabilidad del Código de Buen Gobierno contenido en el Informe Olivencia a las cajas de ahorros, aunque no existan en ellas títulos de propiedad, asimilando los problemas de agencia que subyacen en las relaciones entre accionistas y directivos de las sociedades por acciones "a las que se verifican entre grupos de interés y directivos en sociedades no capitalistas". 
Se han hecho eco de las recomendaciones de los informes citados, entre otras y a título de ejemplo, las Leyes 15/1999, de 16 de diciembre, de Cajas de Ahorros de Andalucía, y 4/2003 de la Comunidad de Madrid, de 11 de marzo, de Cajas de Ahorro. Conforme al artículo 3 de la Ley Andaluza estas entidades deben dotarse de un Código de Conducta y Responsabilidad Social, exigiendo el artículo 73 de la Ley madrileña que las cajas desarrollen, en virtud del principio de autorregulación, normas de conducta y buen gobierno ${ }^{50}$.

La valoración de esta normativa autonómica y, concretamente, de las Disposiciones adicionales $2 .^{a}$ y $4 .^{a}$ de la Ley $26 / 2003$, ha sido dispar por cuanto recogen como obligatorias ciertas conductas que, en opinión de algunos sectores doctrinales, no deberían de ser más que meras recomendaciones en respeto a la autonomía privada y a la autorregulación que deben de asistir a la empresa privada ${ }^{51}$.

No deja de llamar la atención, en efecto, el hecho de que determinadas medidas propugnadas desde el ámbito del gobierno corporativo como de adopción voluntaria para las sociedades, se hayan impuesto, sin embargo, a las cajas de ahorros creando, en este sentido, auténticas obligaciones legales. Más si se toma en consideración que las cajas españolas son un auténtico precedente en lo que a responsabilidad social y equidad en el ejercicio de la actividad económica se refiere ${ }^{52}$.

La irrevocabilidad de los mandatos de los miembros de los órganos de gobierno de las cajas, la limitación temporal de esos mandatos

50 Pontus Hallengren (2005: 55) augura un desarrollo aún mayor a estas prácticas en el seno no sólo de las cajas de ahorros, sino del tejido empresarial español en su conjunto a raíz del anuncio por el gobierno español de la creación de un Consejo de Responsabilidad Corporativa, que actuará como foro de discusión para todos los sectores y sociedades afectadas, permitiendo sentar las bases de sendos proyectos de Ley de Código de sociedades mercantiles y de Ley de responsabilidad corporativa.

51 En este sentido, por todos, Jesús González Pérez (2002: 431 y ss.) a quien parece "excesiva la minuciosidad con que se regulan los instrumentos de información, así como que el contenido y estructura del informe anual del gobierno corporativo venga impuesto por la Administración".

52 Y así, Juan Ramón Quintás Seoane (2003: 24 y ss.) sostiene, entre otros, que las cajas "se han adelantado a esa nueva concepción de la empresa", ya que la responsabilidad social "constituye la esencia de sus principios fundacionales, en muchos casos más que centenarios". También Juan Sánchez-Calero Guilarte (2003: 437), ha subrayado la contradicción que implica reclamar un buen gobierno de entidades como las cajas de ahorros "que unánimemente se afirma que han venido siendo bien gestionadas". En todo caso, la solución por la que se ha optado en relación a las cajas de ahorros enlaza con lo propugnado por el Parlamento Europeo, que se ha pronunciado al respecto con firmeza, aconsejando que se hable, en lo tocante al Libro Verde citado supra, de obligatoriedades y no de meras recomendaciones. 
y de sus posibilidades de reelección, la limitación a un 50 por 100 de los representantes públicos en el gobierno de la entidad, la elaboración de códigos de buen gobierno y de un informe anual de gobierno corporativo, son, todas ellas, medidas contempladas en las Leyes Financiera y de Transparencia, necesarias pero insuficientes, no obstante, si se quiere avanzar realmente en esa proclamada "eficiencia económica", "profesionalización" y "neutralidad" de la actuación de las cajas en el mercado financiero ${ }^{53}$.

Cabe extender a las cajas, en mi opinión, el diagnóstico que realiza el Informe Olivencia al tratar sobre la demanda de reformas en el ámbito societario afirmando que:

el verdadero mal está en las causas y que éstas radican en el desequilibrio que se produce cuando las sociedades concentran excesivamente el poder de dirección en instancias de gobierno en las que no encuentran la debida representación los intereses de los diversos grupos, y en la falta de transparencia y de fluidez en la información, cuando no en la ocultación o en el falseamiento de ésta. De ahí que la exigencia a quienes controlan el gobierno de las sociedades de dar cuenta y razón de su proceder, sea una constante de todo el movimiento reformador. Este principio de buen gobierno, aun teniendo valor en sí mismo, no basta si no va vinculado al de eficacia -al que no puede contraponerse-, en función y al servicio del interés de la sociedad.

Merece, no obstante, una evaluación positiva el esfuerzo que realiza el legislador por incorporar a las cajas de ahorros mecanismos que doten de mayor transparencia a su actuación en el mercado ${ }^{54}$.

53 Rafel Crespí Cladera y Miguel Á. García Cestona (2004: 191 y ss.) reclaman en este sentido una mayor definición y concreción de la misión explícita de las cajas y de sus objetivos, con el fin de "arbitrar mecanismos de gobierno y supervisión" adecuados a su naturaleza fundacional. Álvaro Cuervo García (2003: 79 y ss.) califica, por su parte, de "imperiosa" la necesidad de discutir sobre los derechos de propiedad de las cajas de ahorros y los instrumentos en que se pudiera materializar y sostiene, asimismo, que lo fundamental del buen gobierno de la empresa es que "nadie se sienta descontrolado, lo que le podría llevar a confundir los intereses de la empresa con los suyos propios".

54 Juan Sánchez-Calero Guilarte (2003: 439 y ss.) advierte, en este sentido, cuatro elementos de conexión en las cajas de ahorro con los presupuestos del buen gobierno corporativo: la necesidad de transparencia institucional por su pertenencia al ordenamiento crediticio, la conveniencia de transparencia informativa ante la cotización de las cuotas participativas en los mercados bursátiles, la participación de las cajas, como sociedad dominante incluso, en diversas sociedades cotizadas y, finalmente, la evolución de su régimen jurídico cada vez más cercano, en muchos de sus aspectos, al de las sociedades mercantiles. 
Sobresale, en este sentido, la recién estrenada obligación de redactar un informe de gobierno corporativo, que será objeto de comunicación a la Comisión Nacional del Mercado de Valores, al Banco de España y a los órganos competentes de las Comunidades Autónomas, publicándose además como hecho relevante.

En él se hará constar toda aquella información cuyo conocimiento pudiera afectar a un inversor en la adquisición o transmisión de sus valores, influyendo, por tanto, en su cotización en mercado secundario. Se trata, en definitiva, de plasmar aquella:

información completa y razonada sobre las estructuras y prácticas de gobierno de la entidad que permita conocer los datos relativos a los procesos de toma de decisiones y todos los demás que revelen aspectos importantes del gobierno de la misma, con objeto de tener una imagen fiel y un juicio fundado de la entidad.

Así se afirma expresamente en el Preámbulo de la Orden ECO/354/2004, de 17 de febrero, sobre el informe anual de Gobierno Corporativo y otra información de las Cajas de Ahorros que emitan valores admitidos a negociación en Mercados Oficiales de Valores, que concreta la exigencia que incorpora en tal sentido la Disposición adicional $2 .^{a}$ de la Ley $26 / 2003$, de 17 de julio, de Transparencia. Se avanza así en la senda indicada por el Informe Aldama, en el que se afirma expresamente que "la transmisión de información al mercado no puede ser meramente voluntaria, independientemente de la naturaleza vinculante o no de las reglas o criterios de buen gobierno societario", de forma que:

respecto de estas reglas o criterios ha de exigirse que, como mínimo, las sociedades transmitan al mercado la información sobre cuáles adoptan y cuál es su grado de observancia en cada caso, para que los inversores puedan formarse un juicio correcto sobre esas sociedades.

Qué duda cabe que con ello se pretende promover la eficiencia y racionalidad económica en la caja, frente a decisiones de contenido económico dudosas y de origen claramente político ${ }^{55}$. Conviene recordar aquí, no obstante, y a modo de conclusión, que la responsabilidad

55 No en vano José Antonio Antón Pérez (2004: 369) recuerda que la información que se pone a disposición de inversores e impositores permite a ambos "seleccionar las entidades con las que prefieran operar, potenciando de esta forma el grado de competencia del sistema, al tiempo que se favorece el incremento de la seguridad y de la eficiencia de los mercados". 
de enfrentarse a los retos actualmente planteados a las cajas de ahorros corresponde tan sólo a aquellos que integran sus órganos de gobierno, en aras precisamente del interés social que preside la entidad, y no a los códigos de buen gobierno, ni a las buenas prácticas que pudieran regir su actividad, independientemente de que se apliquen por obligación legal o adscripción voluntaria. Estas reglas tan sólo dan unas pautas sobre el proceso a seguir en la adopción de las decisiones económicas de la entidad, sin que ello sea suficiente, no obstante, para identificar cuál habría de ser la decisión más acertada en función de las circunstancias ${ }^{56}$.

\section{BIBLIOGRAFÍA}

Análisis Financiero (2003), núm. 90, monográfico dedicado al corporate governance.

ANTÓN PÉREZ, José Antonio (1998) "El Informe Olivencia sobre consejos de administración. Su utilidad para las cajas de ahorros", Cuadernos de Información Económica, núm. 132-133, marzo-abril, pp. 189-193.

- (2004) "Legislación financiera y cajas de ahorros. Situación actual", Papeles de Economía Española, núm. 100-I, pp. 361-369.

BARRIOS, Víctor E. (2003) "Un modelo de determinación de la estructura de capital de las cajas de ahorros", Revista Española de Financiación y Contabilidad, núm. 116, enero-marzo, pp. 265-293.

Boletín de Estudios Económicos (2004) núm. 182, agosto, monográfico dedicado al gobierno de la empresa.

CARBó VAlVERde, Santiago y LóPez del PASO, Rafael (2002) "La inclusión financiera: un paso cualitativo más", Cuadernos de Información Económica, núm. 170, septiembre-octubre, pp. 79-90.

CASARES MARCOS, Anabelén (2000) La historia de las cajas de ahorros: origen y evolución. León: Universidad de León.

- (2002) "La naturaleza jurídica fundacional de las cajas de ahorro españolas y su inclusión en el «Tercer Sector»", en MARTín-RETORTILLO BAQUER, Sebastián y TORNOS MAS, Joaquín (Coordinadores), XIII Congreso Italo-Español de Profesores de Derecho Administrativo. Barcelona: Cedecs, pp. 461-497.

56 Juan A. Maroto y Mónica Melle (2001: 167) son tajantes al recordar que los códigos de buen gobierno "distan de ser la panacea que garantice el buen gobierno y los buenos resultados de las empresas". 
- (2003) Cajas de ahorro: naturaleza jurídica e intervención pública. Valencia: Tirant lo Blanch.

- (2005) "La naturaleza fundacional de las cajas de ahorros y la emisión de cuotas participativas", Revista de Administración Pública, núm. 166, enero-abril, en prensa.

CASTELló MUÑOZ, Enrique (2004) "Los valores intangibles en las entidades financieras", Papeles de Economía Española, núm. 101, pp. 282-288.

CECA (2003) Cajas de ahorros: capitales para la sociedad, Madrid.

CRespí Cladera, Rafel y García Cestona, Miguel Á. (2004) "El gobierno de las entidades bancarias: su evolución y el caso de las cajas de ahorros", Papeles de Economía Española, núm. 101, pp. 176-193.

Cuervo García, Álvaro (2003) "El buen gobierno de sociedades y las cajas de ahorros", Economistas, núm. 98, pp. 68-81.

FRANCH MENEU, José Juan (2000) "Sobre cajas de ahorro y competencia", Gaceta Jurídica CE, núm. 208, julio-agosto, pp. 39-42.

GaRCía Delgado, José Luis (Director); JimÉnEZ, Juan Carlos; SÁEZ FERnÁndeZ, Javier y VIAÑA, Enrique (2004) Las cuentas de la economía social. El Tercer Sector en España. Madrid: Civitas.

GaRCíA MANDALONIZ, Marta (2003) "Participación y/o subordinación en los instrumentos de financiación", Revista de Derecho Mercantil, núm. 247, enero-marzo, pp. 279-314.

GARRIDO FalLA, Fernando (1977) Prólogo a la obra de NúÑEZ-LAgos MORENO, Fernando, Aspectos jurídicos del control administrativo de entidades de crédito y ahorro privado. Madrid: EDERSA, pp. XVII-XX.

GÓMEZ JIMÉNEZ, María Pilar (1999) "La emisión de cuotas participativas de Cajas de Ahorros", en MARTínEZ-SIMANCAS Y SÁNCHEZ, Julián y ALONSO UREBA, Alberto (Directores) Instituciones del mercado financiero. Madrid: SOPEC, pp. 4291-4338.

GONZÁLEZ PÉREZ, Jesús (2002) "De la ética al Derecho en la reglamentación de la actividad económica", Anales de la Real Academia de Ciencias Morales y Políticas, núm. 80, curso académico 2002/2003, pp. 409-451.

Hallengren, Pontus (2005) "El marco regulador del gobierno corporativo en España", luris, núm. 91, febrero, pp. 49-55.

HoRnillos, Carlos; LóPEZ YePES, José y Vellosillo, Faustino (1972 a) "Las cajas de ahorros en el siglo XIX. La obra de Don Braulio Antón Ramírez (1823-1892)", Boletín de Documentación del Fondo para la Investigación Económica y Social, volumen IV, fascículo $1^{\circ}$, enero-marzo, pp. 23-31. 
- (1972 b) "Las cajas de ahorros en el siglo XIX. La obra de Don Braulio Antón Ramírez (1823-1892)", Boletín de Documentación del Fondo para la Investigación Económica y Social, volumen IV, fascículo $2^{\circ}$, abriljunio, pp. 245-283.

- (1972 c) "Las cajas de ahorros en el siglo XIX. La obra de Don Braulio Antón Ramírez (1823-1892)", Boletín de Documentación del Fondo para la Investigación Económica y Social, volumen IV, fascículo $3^{\circ}$, julioseptiembre, pp. 504-533.

KEMPSON, E. y WHYLEY, C. (1999) Kept out or opted out? Understanding and combating financial exclusion. Bristol: The Policy Press.

LÓPEZ DEL PASO, Rafael (2003) "Las cajas de ahorros en el continente europeo: un modelo llamado a persistir", Cuadernos de Información Económica, núm. 176, septiembre-octubre, pp. 143-150.

LÓPEZ YePES, José y TITOS MARTíneZ, Manuel (2000) Braulio Antón Ramírez. Las cajas de ahorros en el siglo XIX. León: Caja España.

MAI, Heike (2004) "Spaniens Cajas: Wirtschaftlich freier, aber nicht entpolitisiert", EU-Monitor Finanzmarkt Spezial, núm. 20, octubre, pp. $1-20$.

MAROto Acín, Juan Antonio (1999) "¿Gobierno de las cajas, o cajas de los gobiernos?", Economistas, núm. 80, marzo, pp. 205-211.

MAROTO, Juan Antonio y MELLE, Mónica (2001) "El gobierno de las empresas bancarias en la Unión Europea: rasgos distintivos, códigos de buen gobierno y performance", Perspectivas del Sistema Financiero, núm. 73, pp. 161-183.

MARTÍN-ReTORTILLO BAQUeR, Sebastián (1991) "Sistema bancario y crediticio", en la obra colectiva dirigida por él, Derecho administrativo económico. Madrid: La Ley, Tomo II, pp. 39-277.

MARTínez MARTíneZ, María Teresa (2002) Las inscripciones registrales de las cajas de ahorros. Madrid: EDERSA.

MARTínez SOTO, Ángel Pascual (2000) "Las cajas de ahorros españolas en el siglo XIX: entre la beneficencia y la integración en el sistema financiero", Revista de Historia Económica, núm. 3, pp. 585-628.

Moraleda García de los Huertos, Francisco (2003) "La eficiencia de las soluciones conjuntas en los nuevos servicios de las cajas", Economistas, núm. 98, pp. 147-155.

PAMPILlón, Fernando (2004) "Cajas de ahorros, seguridad y posición frente a Basilea II", Papeles de Economía Española, núm. 100-I, pp. 321-338. 
Papeles de Economía Española (2003), núm. 97, monográfico dedicado a los orígenes de las cajas de ahorros.

QUINTÁs SEOANE, Juan Ramón (2003) "Las cajas de ahorros españolas en el siglo XXI: modernización y capital social", Perspectivas del Sistema Financiero, núm. 77, pp. 1-25.

- (2004) "La gestación del modelo español de cajas", Papeles de Economía Española, núm. 100-I, pp. 268-280.

REVELL, Jack (1989) El futuro de las cajas de ahorros. Estudio de España y el resto de Europa. Madrid: CECA.

SÁnCHEZ-CALERo GUILARTE, Juan (2003) "Las modificaciones en el régimen de las Cajas de Ahorro", en SÁnCHEZ CALERO, Fernando y SÁNCHEZ-CALERO GUILARTE, Juan (Coordinadores) Comentario a la Ley 44/2002, de 22 de noviembre, de Medidas de Reforma del Sistema Financiero. Elcano: Aranzadi, pp. 431-472.

TAPIA HeRmidA, Alberto Javier (1991) "La financiación externa de las cajas de ahorros, en particular las obligaciones subordinadas y las cuotas participativas", Revista de Derecho Bancario y Bursátil, núm. 43, julioseptiembre, pp. 687-743.

- (2003) "Las cuotas participativas de las cajas de ahorros", en SÁnCHEZ CAlero, Fernando y SÁNCHEZ-CALERO GUILARTE, Juan (Coordinadores) Comentario a la Ley 44/2002, de 22 de noviembre, de Medidas de Reforma del Sistema Financiero. Elcano: Aranzadi, pp. 473-505.

UREÑA SALCEDO, Juan Antonio (2002) "La consideración de algunos créditos y participaciones empresariales de las cajas de ahorros como ayudas públicas", Derecho Comunitario Europeo, núm. 11, enero-abril, pp. 155-176.

VAleRo, Francisco José y ESTEBAN CRESPO, Sergio (2000) "Recursos propios y solvencia en las Cajas de Ahorros. Posibilidades que brindan las cuotas participativas", Análisis Financiero Internacional, núm. 102, octubrediciembre, pp. 27-38.

VAlero, Francisco José y García Mora, Alfonso (2004) "La valoración de las cajas de ahorros ante la emisión de cuotas participativas", Economistas, núm. 101, pp. 68-79.

VAlLE SÁnCHEZ, Victorio (2004) "El «dividendo social» de las cajas de ahorros españolas", Papeles de Economía Española, núm. 100-I, pp. 281-305.

VAÑó VAÑó, María José (2000 a) "En torno a la pretendida crisis de la naturaleza jurídica de las cajas de ahorros", Revista General de Derecho, núm. 672, pp. 11375-11389. 
- (2000 b) "Legitimación en el nombramiento de representantes en los órganos rectores de las cajas de ahorros y criterios en la designación de los mismos", en Cuñat Edo, Vicente y Ballarín Hernández, Rafael (Directores) Estudios sobre jurisprudencia bancaria. Pamplona: Aranzadi, pp. 595-626. 